\title{
Hardwood Rangeland Landowners in California from 1985 to 2004: Production, Ecosystem Services, and Permanence
}

\author{
Lynn Huntsinger, ${ }^{1}$ Martin Johnson, ${ }^{2}$ Monica Stafford, ${ }^{2}$ and Jeremy Fried ${ }^{3}$
}

Authors are ${ }^{1}$ Professor and ${ }^{2}$ Graduate Student Researchers, Environmental Science, Policy, and Management, University of California, Berkeley, CA 94720, USA; and ${ }^{3}$ Research Forester, Pacific Northwest Forest and Range Experiment Station, Portland, OR 97230, USA.

\begin{abstract}
A longitudinal study of California hardwood rangelands shows significant change in landowner characteristics and goals. Results of three studies spanning 1985 to 2004 were used to develop and evaluate a multiagency research and extension program known as the Integrated Hardwood Range Management Program. Program-sponsored education and research aimed at encouraging landowners to change woodland management has been reflected in a significant reduction in oak cutting and an increase in oak planting. Recent changes have come with the times: landowners were as likely to have consulted land trusts about oaks as Cooperative Extension, and the number engaged in production of crops or livestock continued to decline. On the other hand, the proportion of landowners, including ranchers, reporting that they live in the oak woodland to benefit from ecosystem services such as natural beauty, recreation, and lifestyle benefits significantly increased. Though owners of large properties and ranchers were more strongly against regulation and "government interference" than other respondents, this did not appear to affect oak values and management. Property size remained significantly related to landowner goals, values, and practices, with those producing livestock owning most of the larger properties. There has been a decline in the number of properties being studied due to conversion of some from oak woodland to other uses, though the remaining respondents still own at least $10 \%$ of the woodlands. Landowners with conservation easements or those who are willing to consider them, who believe oak recruitment is inadequate, or who use advisory services were significantly less likely to cut oaks and more likely to plant them. Policy, management, and outreach that support synergies between production and conservation activities, and that combine ecosystem service-based income streams that encourage keeping land intact and increased land-use stability, are needed to support conservation of private rangelands.
\end{abstract}

\section{Resumen}

Un estudio longitudinal en California de pastizales asociados con bosques dotados de especies de madera dura indica un cambio significativo en las características y metas de los propietarios de la tierra. Los resultados de los tres estudios que abarcan los años 1985 a 2004 se utilizaron para desarrollar un programa interinstitucional conocido como el Programa de Manejo Integral de los Pastizales asociados a Bosques de Especies de Madera Dura. Este proyecto implementó programas de investigación y extensión con el objetivo de promover cambios en el la gestión del monte que reflejan en una disminución significativa en la tala de Quercus, y un alzo en la superficie plantado a especies quercineas. Otros cambios son el reflejo de los tiempos actuales: la probabilidad de que los propietarios realizaran consultas sobre la gestión del monte a fundaciones para la conservación de la tierra o al servicio de Extensión Cooperativa fue similar, mientras que la proporción de propietarios involucrados en la producción de cultivos o ganado continúa declinando. Por otra parte, se aumenta el porcentaje de propietarios, incluyendo productores, que viven en áreas de monte quercinea para beneficiarse de servicios ambientales como la belleza natural, la recreación, y los beneficios del estilo de vida. Aunque los dueños de propiedades más grandes y los productores en general mostran una oposición más enérgica a la regulación y la "interferencia por parte del gobierno," aparentemente esta actitud no estuvo asociada con los valores de conservación y gestión del monte. El tamaño de las propiedades continuó estando significativamente asociada con las metas, valores, y prácticas realizadas por los propietarios; quienes producían ganado poseían las propiedades más grandes. Ha habido una reducción en el número de la muestra de propiedades por la conversión del quercineas a otros usos, si bien los respondientes que permanecieron en el estudio poseen al menos un $10 \%$ del área de monte. Propietarios que poseían comodatos de conservación de la tierra, o que estaban dispuestos a considerar dichos comodatos, o quienes pensaban que el reclutamiento de robles es inadecuado, eran significativamente menos proclives a talar quercineas y más proclives a plantar quercineas. Es deseable sotener una politica, gestión, e consultas con expertos que enlacen conservación y provalucción, crear una sistema que favorece pago a propriatarios para servicios ambientales, ye mantner intacto sus propriedades y no vender sus terrenos.

Key Words: attitudes, conservation easements, impermanence syndrome, land use, management, Quercus

Research was funded by the Integrated Hardwood Range Management Program of the University of California, the California Agricultural Experiment Station, and the California Division of Agriculture and Natural Resources CORE grant program.

Correspondence: Lynn Huntsinger, ESPM-ES, 137 Mulford Hall, University of California, Berkeley, CA 94720, USA. Email: Huntsinger@berkeley.edu

Manuscript received 18 July 2008; manuscript accepted 11 January 2010 


\section{INTRODUCTION}

Development of programs for influencing management of private rangelands should be based on a strong understanding of landowner goals, needs, and circumstances (Coppock and Birkenfield 1999). A survey approach is often chosen for such an assessment, and for understanding the factors that influence manager decisions. Previous rangeland survey research has linked management practices and goals to aspects of property or operation size (Huntsinger and Fortmann 1990; Rowe et al. 2001; Kreuter et al. 2004); land tenure (Fortmann and Huntsinger 1989; Rowe et al. 2001; Sulak et al. 2008); length of ownership (Gosnell et al. 2007); attitudes toward government, regulation, and property rights (Liffmann et al. 2000; Jackson-Smith et al. 2005; Kreuter et al. 2006; Conley et al. 2007); surrounding levels of urbanization (Liffmann et al. 2000; Sulak and Huntsinger 2002; Huntsinger et al. 2004; Yung and Belsky 2007; Sulak et al. 2008); incentives programs (Huntsinger et al. 2004; Larson et al. 2005); education (Richards and George 1996; Coppock and Birkenfeld 1999); income (Coppock and Birkenfeld 1999); income source (Kreuter et al. 2004); and region (Rowan and White 1994). Several studies have developed typologies of rangeland landowner characteristics and behaviors (Gentner and Tanaka 2002; Brodt et al. 2004; Gosnell and Travis 2005). Though important to understanding rangeland management, none of these surveys followed management over time, something that is needed to assess trends.

In the natural resource sciences, longitudinal surveys of landowners are rare. Research sponsored by California's multiagency Integrated Hardwood Range Management Program (IHRMP) provides an opportunity to follow management over time. When the program began in 1985, a property-based survey of hardwood rangeland (also referred to as oak woodland or foothill woodland) landowners was conducted in order to develop extension programs and research targets. The objective was to identify the goals and practices of hardwood rangeland landowners and to examine relationships between landowner characteristics, values, and management. The survey was repeated when funding and personnel were available, in 1992 and 2004, with the objectives of identifying changes in landowner characteristics, practices, land uses, and attitudes over time in order to update education and research activities, and to provide information for legislators considering regulation of oak harvest. Results of the 1985 survey were published in 1990 (Huntsinger and Fortmann 1990) and compared landowners with properties of less than 80 ha, between 80 ha and 2008 ha, and more than 2008 ha. A comparison of the 1985 and 1992 surveys was published in 1997 (Huntsinger et al. 1997). Here we compare the results of the third survey to those from the earlier surveys, covering a period of almost $20 \mathrm{yr}$.

Most oak woodlands are privately owned. Development and overharvest, coupled with inherently variable and often low levels of oak recruitment, put them at risk. As coordinated among the University of California Cooperative Extension, CalFire, and other agencies, IHRMP goals at the outset included reducing the loss of oaks in the state and researching ways to encourage oak-positive management of the woodlands by landowners. Areas of inquiry in the survey include

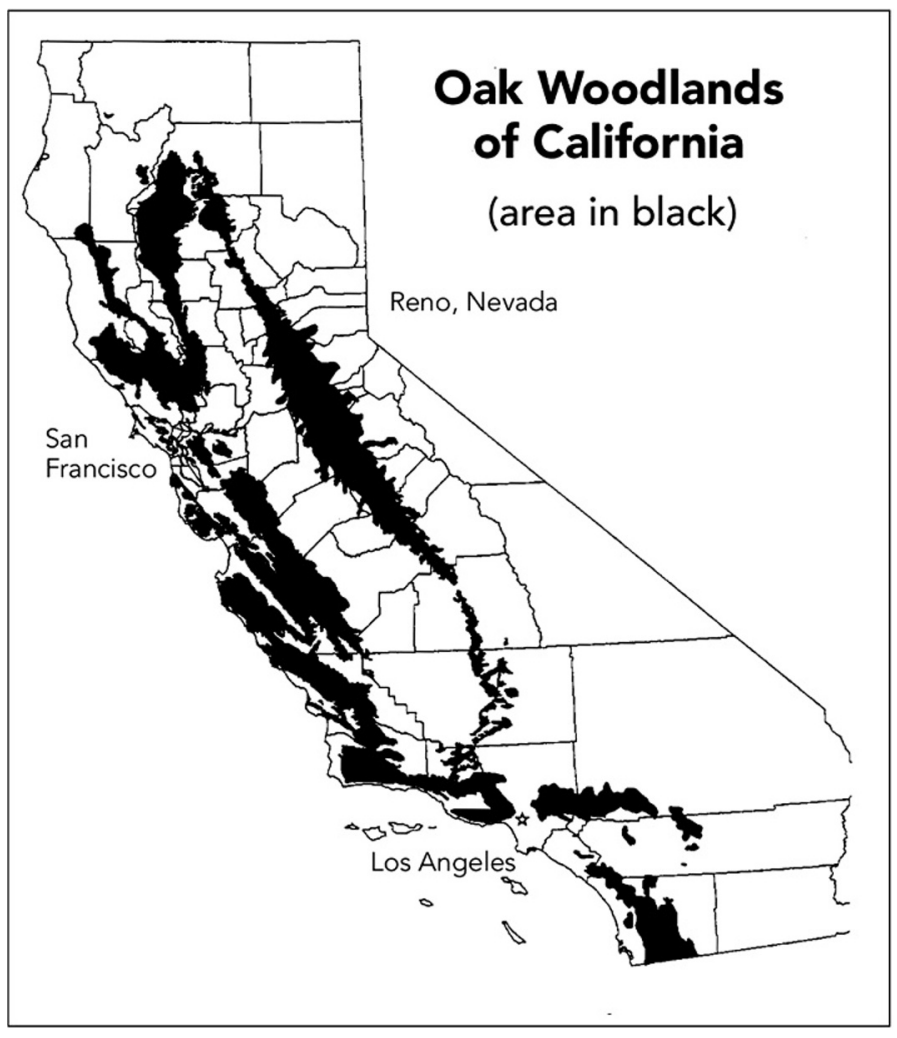

Figure 1. Distribution of hardwood rangelands in California (Allen-Diaz et al. 2007).

landowner demographics, how and why landowners are managing their oaks, what they use and value oaks for, their motives for living in the oak woodlands, their receptivity to environmental regulation, where they get management information from, their participation in conservation programs, and whether or not they are involved in production agriculture. Each is important for developing outreach and further research.

\section{California's Hardwood Rangelands}

The 2 million ha of California hardwood rangeland (California Department of Forestry and Fire Protection-Fire and Resource Assessment Program [CDF-FRAP] 2003) are characterized by an oak (Quercus spp.) overstory and annual grass understory; they occupy coastal and valley foothills throughout most of the state in the Mediterranean climate zone from sea level to about 2000-m elevation (Fig. 1; Allen-Diaz et al. 2007). Canopy cover varies from complete closure in canyon thickets to open savanna woodlands on foothill slopes (Allen-Diaz et al. 1999, 2007). California's oak woodlands have been recognized worldwide as significant for biodiversity conservation as part of the California floristic province biodiversity hot spot (Myers et al. 2000). More than $80 \%$ of the woodlands are in private ownership (CDF-FRAP 2003), and grazing has been the dominant use since European settlement (Burcham 1982). Oak woodland landowners in California are notable for their production of diverse ecosystem services and for the value landowners place on private amenity benefits from woodland ownership (Campos et al. 2009).

The woodlands are also highly desirable for residential development (Huntsinger and Hopkinson 1996). A comparison 
of 1982 and 2002 oak woodland data from the State of California shows a decline in woodland extent of almost a third, though changes in methodology and plant community classification make this estimate a rough one (Ewing et al. 1986; CDF-FRAP 2003; Huntsinger et al. 2008). In addition to fragmentation from development, there is concern about a lack of oak recruitment in some areas (Muick and Bartolome 1987). In 1985, the harvest of oaks for fuel and for increased forage production, and the impacts of grazing on oak seedlings were identified as potential contributing factors. Since then, further study has indicated that regeneration and recruitment vary greatly by geographic location and substrate, and are limited or stimulated by a variety of factors not necessarily related to management (Tyler et al. 2006).

Though a variety of other surveys have been conducted in California's hardwood rangelands during the study period (McClaran and Bartolome 1985, Stewart 1991, Johnson 1997, Larson et al. 2005), none have been based on a randomly selected, statewide sample of hardwood rangeland ownerships. However, they have generally supported the results of the 1985 and 1992 surveys (Huntsinger et al. 1997), showing that the majority of landowners value at least some oaks on their property for a variety of reasons and are most often actively managing them. Field-based inventory and monitoring projects examining land use and oak management practices have also helped verify the results of the 1985 and 1992 surveys (Huntsinger et al. 1997), finding, for example, that about two-thirds of hardwood rangelands are grazed by livestock and that conversion and fragmentation are serious problems (Bolsinger 1988; Ewing et al. 1988; Holzman 1993; Swiecki et al. 1997).

\section{METHODS}

\section{Survey Design}

Sampling and methodology is consistent for all three surveys, but in 2004 questions were added about conservation easements and land trusts because of their high visibility in oak woodland conservation. Surveys were pretested, and then owners of hardwood rangeland throughout the state were surveyed by mail, using the standard four-wave technique described by Dillman (1978) to achieve a high response rate. The greater the response rate, the less "self-selection" bias influences responses and hence the more representative the sample (Clendenning et al. 2004).

Questionnaires were sent to owners of land containing the Forest Inventory Assessment plots previously used to assess hardwood volume in California (Bolsinger 1988). Plots were established at the intersection points of a randomly established $11-\mathrm{km}^{2}$ grid overlaid on the state. Plots designated as the nonindustrial forest "hardwood woodland type" by the Pacific Northwest Field Experiment Station (US Department of Agriculture, Forest Service 1981) were selected if an overstory of $10 \%$ or greater canopy cover was predominately Quercus species and the plot was on private land. Selected plots occurred in 38 of the state's 58 counties, at elevations ranging from $80 \mathrm{~m}$ to $1800 \mathrm{~m}$.

Usable questionnaires were returned by 126 of 166 eligible respondents for a response rate of $76 \%$ in $1985 ; 121$ of 151 eligible respondents for a response rate of $80 \%$ in 1992; and 98 of 154 eligible respondents in 2004 for a response rate of $64 \%$. Despite losses from the sample population due to subdivision of properties that made locating new owners often impossible, an estimated $10 \%$ or more of California's hardwood rangelands were owned by the respondents at each date. The 2004 respondents include those who purchased, inherited, or took over management of a family property since 1985, and some who did not respond to previous surveys, as well as those maintaining ownership of the property since 1985 .

The grid method used to establish forest inventory plots means that larger properties have a greater probability of being selected (Wensel 1983). Although this resulted in good representation of landowners of each property size, responses about land use practices cannot be directly extrapolated to the hardwood rangeland as a whole. Analysis using a sample weighted inversely to property size (if property size $\leq$ grid size, weight $=$ grid size/property size; if property size $>$ grid size, weight $=1$ ) can be used to extrapolate to a spatial proportion of the oak woodland meeting our selection criteria (Wensel 1983). Another consideration is that although a landowner may report "cutting oaks," we do not know how many oaks or hectares the landowner cut.

The $\chi^{2}$ statistic was used to determine significance for categorical variables, whereas Student's $t$ test was used to compare continuous variables such as age or property size (Spicer 1972). Unless otherwise stated, statistical comparisons were between 1985 and 2004 responses to survey questions, using the $\chi^{2}$ statistic. With our small sample size, the low cost of a type I error in this case, and our desire to identify variables for further study, we chose to prioritize avoiding type II error and used the $P<0.1$ level for interpreting results as significant (Kreuter et al. 2006; Labovitz 2006). However, we have presented all $P$ values smaller than 0.2 so that the reader may prioritize avoiding error as desired. Small sample size precluded multivariate analysis. Questions are condensed in the tables presenting results.

\section{RESULTS}

\section{Owner Characteristics and Rangeland Use}

There has been no significant change in landowner demographics, but significantly fewer owners are earning their income from ranching, and more are relying on "other sources" of income, such as investments, pensions, and self-employment (Table 1). In 2004, respondents owned a total of 272000 ha. Using the weighted sample, an estimated $20 \%$ of the woodlands belong to absentee owners, and $17 \%$ belong to landowners with a paid property manager.

There have been significant changes in land use since 1985 . The number of owners selling livestock, and with livestock grazing on their property, declined (Table 2). Yet more than $80 \%$ of properties larger than 80 ha are grazed by livestock, a proportion that has not significantly changed since 1985. In $1985,78 \%$ of landowners with livestock grazing on their property sold livestock, compared to $62 \%$ in $2004(P<0.04$, $\mathrm{df}=2$ ), indicating increased grazing by lease. Using the weighted sample, an estimated $10 \%$ of grazed woodlands are owned by those who do not produce or sell livestock (Table 2). Though this was not asked about on previous survey dates, in 
Table 1. The percentage of California hardwood rangeland landowners with the following characteristics in 1985, 1992, and 2004.

\begin{tabular}{|c|c|c|c|c|}
\hline \multirow[b]{2}{*}{$\begin{array}{c}\text { Landowner } \\
\text { characteristics }\end{array}$} & \multicolumn{3}{|c|}{ Landowners (\%) } & \multirow[b]{2}{*}{$\begin{array}{c}P\left(\chi^{2}\right), \mathrm{df}=1 \\
1985 \text { vs. } 2002\end{array}$} \\
\hline & $\begin{array}{c}1985 \\
(n=126)^{1}\end{array}$ & $\begin{array}{c}1992 \\
(n=115)^{1}\end{array}$ & $\begin{array}{c}2004 \\
(n=98)^{1}\end{array}$ & \\
\hline College graduate & 50 & 54 & 60 & $n s^{2}$ \\
\hline Mean age & 58 & 58 & 61 & $\mathrm{~ns}^{3}$ \\
\hline $\begin{array}{l}\text { Mean length of ownership } \\
\text { of land }\end{array}$ & 35 & 44 & 39 & \\
\hline Major source of income & & & & $n s^{3}$ \\
\hline Ranching & 27 & 20 & 14 & 0.02 \\
\hline Other self employed & 31 & 29 & 24 & ns \\
\hline Wage employment & 27 & 29 & 31 & ns \\
\hline Other & 15 & 20 & 32 & 0.00 \\
\hline Absentee owner & 25 & 26 & 22 & ns \\
\hline Have a paid manager & 22 & 16 & 10 & 0.02 \\
\hline Female & 18 & 24 & 20 & ns \\
\hline
\end{tabular}

${ }^{1} n$ varies slightly with each question.

${ }^{2} \mathrm{~ns}$ indicates not significant.

${ }^{3} P>0.1$, Student's $t$ test.

$200410 \%$ of respondents grazed stocker cattle only, another $18 \%$ grazed stockers with a cow-calf herd, and $32 \%$ of respondents grazed a cow-calf herd only. Approximately 4\% grazed sheep, $4 \%$ grazed llamas, and 3\% grazed goats.

Selling fuelwood declined significantly, and fee hunting and fishing remains small and without detectible trend (Table 2). The proportion of owners with their land enrolled under the California Land Conservation Act of 1965 (CLCA) or in a Timber Production Zone, two voluntary conservation programs that limit land development for $10 \mathrm{yr}$ in exchange for tax relief, has remained steady. Three landowners in our sample had worked with Cooperative Extension to create a rangeland water quality management plan for their properties as part of voluntary compliance with the state's Clean Water Act (Larson et al. 2005), and one landowner reported participating in the California Department of Fish and Game's Ranching for
Wildlife program (AB 580), which provides benefits to landowners who improve habitat. All three owned more than 2008 ha.

\section{Goals and Motivations of Landowners}

The motives landowners gave for choosing to live in the oak woodland changed dramatically and significantly from those given in 1985, with amenities such as recreation, natural beauty, getting away from the city, and having a different lifestyle becoming significantly more important (Table 3 ). Considering livestock sellers or ranchers only, the trends are the same, with amenities much more important in 2004. At all three survey dates, more than $60 \%$ of ranchers reported a family business or property as an important reason to live in the oak woodlands, but in $2004,86 \%$ of ranchers reported that the natural beauty of the oak woodlands was important, compared to $59 \%$ in $1985(P<0.08, \mathrm{df}=4)$. Though it was only asked about in 2004, 59\% of ranchers stated that hunting and fishing influenced their choice, and $82 \%$ said that opportunities to view wildlife influenced them.

Unlike other responses analyzed in this survey, significant changes in motives for living in the oak woodland were reported by landowners in the three property sizes between 1985 and 2004 (Fig. 2). In 1985, owners of $<80$ ha were highly influenced by the amenities of owning oak woodlands, including lifestyle, getting away from the city, natural beauty, and recreational opportunities (Huntsinger and Fortmann 1990), whereas owners of more than 2008 ha were significantly less likely to report these as important influences. In 2004, however, owners of more than 2008 ha much more frequently reported being motivated by such amenities, with $30 \%$ saying "having a different lifestyle" was an important influence in 1985 , and $76 \%$ saying it was in 2004 (Fig. 2; $P<0.027, \mathrm{df}=4$ ). Summing the four amenity variables above (notated in Table 2) into an "amenity" score (Table 3) with a higher total indicating more amenity values, the score for properties of less than 80 ha has not changed significantly over time, with a mean of 15.3 in 1985 , and 16.6 in 2004. On the other hand, for landowners with more than 2008 ha the score increased significantly from a mean of 9.1 in

Table 2. The percentage of California hardwood rangeland landowners engaged in each land use in 1985, 1992 , and 2004.

\begin{tabular}{|c|c|c|c|c|c|}
\hline \multirow[b]{2}{*}{ Land use } & \multicolumn{3}{|c|}{ Landowners (\%) } & \multirow[b]{2}{*}{$P\left(\chi^{2}\right), \mathrm{df}=1,1985$ vs. 2004} & \multirow{2}{*}{$\begin{array}{c}\text { Estimated \% } \\
\text { ha } 2004^{2}\end{array}$} \\
\hline & $1985(n=126)^{1}$ & $1992(n=115)^{1}$ & $2004(n=98)^{1}$ & & \\
\hline Cattle/sheep graze property & 73 & 63 & 62 & 0.09 & 66 \\
\hline Produces livestock & 65 & 58 & 52 & 0.04 & 56 \\
\hline Sells livestock & 61 & 55 & 41 & 0.00 & 42 \\
\hline Sells fuelwood & 20 & 11 & 9 & 0.03 & 9 \\
\hline Sells any products from land & 68 & 63 & 47 & 0.00 & 48 \\
\hline Produces food crops & 20 & 18 & 21 & $n s^{3}$ & 28 \\
\hline Sells fee hunting or fishing & 11 & 9 & 8 & ns & 9 \\
\hline Uses as vacation home & 15 & 23 & 20 & ns & 18 \\
\hline \multicolumn{6}{|l|}{ Land registered in California Land } \\
\hline Conservation Act & 51 & 45 & 46 & & 50 \\
\hline Land in Timber Production Zone & 9 & 16 & 14 & ns & 16 \\
\hline
\end{tabular}


Table 3. The percentage of California hardwood rangeland landowners who agreed that the following factors strongly influenced their decision to live in hardwood rangelands in 1985, 1992, and 2004.

\begin{tabular}{|c|c|c|c|c|}
\hline \multirow[b]{2}{*}{ Factors } & \multicolumn{3}{|c|}{ Landowners (\%) } & \multirow[b]{2}{*}{$\begin{array}{l}P\left(\chi^{2}\right), \mathrm{df}=2, \\
1985 \text { vs. } 2004\end{array}$} \\
\hline & $\begin{array}{c}1985 \\
(n=126)^{1}\end{array}$ & $\begin{array}{c}1992 \\
(n=115)^{1}\end{array}$ & $\begin{array}{c}2004 \\
(n=98)^{1}\end{array}$ & \\
\hline \multicolumn{5}{|l|}{ I wanted to live near natural } \\
\hline beauty & 46 & 60 & 71 & 0.00 \\
\hline Job opportunities & 21 & 19 & 10 & 0.09 \\
\hline To get away from city life & 39 & 41 & 54 & 0.09 \\
\hline \multicolumn{5}{|l|}{ So I could have a different } \\
\hline lifestyle & 29 & 35 & 48 & 0.00 \\
\hline Recreational opportunities & 31 & 30 & 43 & 0.03 \\
\hline It is cheaper to live here & 9 & 12 & 10 & $n s^{2}$ \\
\hline Family business or property & 55 & 57 & 48 & ns \\
\hline \multirow{2}{*}{\multicolumn{5}{|c|}{$\begin{array}{l}\text { Hunting and fishing-2004 } \\
\text { only }\end{array}$}} \\
\hline & & & 21 & \\
\hline View wildlife-2004 only & - & - & 45 & $m m^{2}$ \\
\hline
\end{tabular}

1985 to 12.9 in $2004(P<0.07, t$ test $)$, though the difference in amenity scores of landowners with less than 80 ha and more than 2008 ha remained significant in 2004 (mean $=12.9$ vs. 16.6; $P<0.08, t$ test).

\section{Memberships and Sources of Information}

Changes in memberships reflect the trends away from production land use, and trends in consultation reveal the importance of land trusts (Table 4). Landowners were asked if they had consulted with an advisory service during the "last

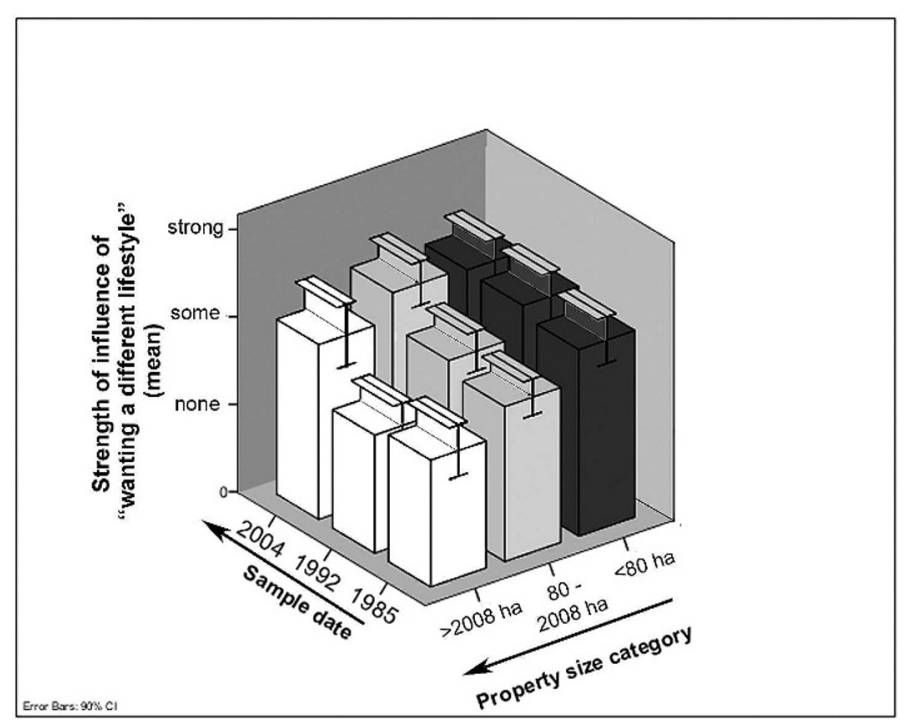

Figure 2. The influence of "having a different lifestyle" on landowner decisions to live in the oak woodlands in 1985, 1992, and 2004 (error bars are the $90 \%$ confidence interval of the mean). There was no change in relative values by property size in 1985 and 1992, but in 2004, owners of properties larger than 80 ha were significantly more likely to report being influenced by the desire to have a different lifestyle than they were in $1985\left(P<0.02, \chi^{2}, \mathrm{df}=2\right)$. Very similar patterns and levels of significance were found for being "influenced by natural beauty." two years," and more than a third had done so. Cooperative Extension, the Natural Resources Conservation Service, and land trusts were most commonly used.

\section{Attitudes Toward Government and Regulation}

The generally negative attitude of oak woodland landowners toward government regulation and control observed in 1985 continued to be observed in 2004 (Table 5). About half of all landowners continue to agree that regulation with compensation is acceptable, though few believe that citizens are adequately consulted. One significant trend is that landowners are less likely to believe that landowners should be able to use the natural resources on their property without state permission. Based on a scale developed from the variables notated in Table 5, excluding oak-related variables, with a higher total indicating greater opposition to regulation, landowners in the largest size category (mean $=17.7$ vs. $14.2 ; P<0.01, t$ test), and ranchers (mean $=18.2$ vs. $14.8 ; P<0.01, t$ test), were more likely than other respondents to be opposed to a strong government regulatory role in natural resources management. On the other hand, opposition to regulation did not relate to landowner oak management practices, values for oaks, motivations for living in the woodlands, age, or land tenure. Owners of properties greater than 2008 ha were significantly more likely to agree that oak are being lost in 2004 (56\%) than in $1985(21 \% ; P<0.03, \mathrm{df}=1)$.

\section{Landowner Management Practices and Values for Oaks}

Landowners were asked if they had carried out specific practices during the previous $5 \mathrm{yr}$, and about their values for oaks. In 2004 they reported more reasons to value and plant oaks, and less oak cutting than in previous surveys (Table 6). In 1985, owners of properties greater than 2008 ha were more likely to cut oaks than those with properties of less than 80 ha $(P<0.05, \mathrm{df}=1)$, but there was no significant difference by property size category in 2004 (Table 6), with a lower proportion of all owners cutting oaks.

In 2004, cutting living oaks was related to perceptions of oak replacement, oak canopy cover, the overall status of oaks, and the value of oaks for beauty, soil holding, and water conservation (Table 7). About $56 \%$ of owners said there were enough "young oaks coming up to replace the old oaks," $25 \%$ of owners reported that young oaks were insufficient to replace the old oaks, and $18 \%$ reported that they did not know. Planting oaks is related to making use of advisory services, perceptions of oak replacement, residence on property, and valuing oaks for habitat, natural beauty, browse, and water conservation (Table 7). Property size, income level, ranching, oak canopy cover, receptivity to government intervention, CLCA participation, belief oaks are being lost, cutting oaks, gender, and education level had no relationship to planting oaks, and neither did valuing oaks for shade, property values, water conservation, soil holding, and forage.

\section{Conservation Easements and Land Trusts}

In 2004 six landowners, owning together more than 10000 ha, reported having conservation easements (Table 8). Each easement covered half or more of the property, and four of the six landowners produced livestock. Two easements were 
Table 4. Percentage of California hardwood rangeland landowners who belonged to, or got advice from, the following organizations in 1985, 1992, and 2004.

\begin{tabular}{|c|c|c|c|c|}
\hline & \multicolumn{3}{|c|}{ Landowners (\%) } & \multirow[b]{2}{*}{$P\left(\chi^{2}\right), \mathrm{df}=1,1985$ vs. 2004} \\
\hline & $1985(n=126)^{1}$ & $1992(n=115)^{1}$ & $2004(n=98)^{1}$ & \\
\hline \multicolumn{5}{|l|}{ Landowner memberships and use of advice } \\
\hline Member of wildlife or environmental group & 25 & 30 & 31 & $n s^{2}$ \\
\hline Member of livestock association or farm bureau & 58 & 49 & 41 & 0.06 \\
\hline \multicolumn{5}{|c|}{ Consulted the following during the $2 \mathrm{yr}$ previous to the survey about oaks } \\
\hline Private tree consultant & 9 & 12 & 7 & ns \\
\hline Cooperative Extension & 7 & 15 & 16 & 0.05 \\
\hline Department of Fish and Game & 7 & 7 & 12 & ns \\
\hline Natural Resource Conservation Service & 6 & 6 & 15 & 0.02 \\
\hline Any advisory service & 24 & 26 & 37 & 0.04 \\
\hline Book-2004 only & - & - & 23 & $n a^{2}$ \\
\hline Land Trust-2004 only & - & - & 17 & na \\
\hline
\end{tabular}

${ }^{1} n$ varies slightly with each question.

${ }^{2}$ ns indicates not significant; na, not applicable.

established prior to 1990. One landowner purchased the land with a conservation easement on it. The trust holder for each differed, including three different county land trusts, a local open space district, a state agency, and a statewide land trust. Landowner motives were equally variable, including tax relief for two owners. One landowner said he/she wanted to preserve land for heirs, another wanted to obtain funds to reinvest in the property, and another wanted to leave a legacy. However, the most common response, given by four landowners, was simply to "conserve the land." Four said that if they "knew then what they know now" they would put an easement on it again, or purchase the land with an easement. The two who would not choose to have an easement if they had it to do over again had the smallest proportion of their land in easement, and both easements were donated rather than sold.

Although 3204 ha \pm 1362 SE $(n=85)$ was the mean property size of respondents who knew what a conservation easement was in 2004, the mean property size of those who did not know about easements was 29 ha \pm 12 SE $(n=10$; Table 8). Those who had an easement or would consider acquiring one were significantly more likely to plant oaks and less likely to cut oaks than other property owners (Table 7). Though it was only asked about in 2004, two-thirds of landowners reported that they planned to keep their land intact for the next $10 \mathrm{yr}$, whereas $11 \%$ reported that they planned to sell or give away all or part of their property within

Table 5. The percentage of California hardwood rangeland landowners with the following attitudes toward regulation in 1985,1992 , and $2004{ }^{1}$

\begin{tabular}{|c|c|c|c|c|}
\hline \multirow[b]{2}{*}{ Respondents agree that: } & \multicolumn{3}{|c|}{ Landowners (\%) } & \multirow[b]{2}{*}{$P\left(\chi^{2}\right), d f=1,1985$ vs. 2004} \\
\hline & $1985(n=126)^{2}$ & $1992(n=115)^{2}$ & $2004(n=98)^{2}$ & \\
\hline $\begin{array}{l}\text { State regulation means a loss of liberties and } \\
\text { freedom }^{3}\end{array}$ & 82 & 88 & 74 & 0.13 \\
\hline $\begin{array}{l}\text { State can regulate private land resource } \\
\text { management }^{3}\end{array}$ & 22 & 25 & 30 & $\mathrm{~ns}^{4}$ \\
\hline State can regulate private land with compensation ${ }^{3}$ & 46 & 53 & 47 & ns \\
\hline Oaks are being lost in California & 59 & 79 & 77 & 0.02 \\
\hline Oak use should be regulated & 32 & 39 & 43 & 0.15 \\
\hline $\begin{array}{l}\text { Protecting water quality should be a state } \\
\text { responsibility }^{3}\end{array}$ & 88 & 85 & 83 & ns \\
\hline $\begin{array}{l}\text { The state consults adequately with citizens before } \\
\text { regulating resources }{ }^{3}\end{array}$ & 21 & 22 & 17 & ns \\
\hline $\begin{array}{l}\text { State has a responsibility to protect natural } \\
\text { resources }\end{array}$ & 80 & 81 & 83 & ns \\
\hline $\begin{array}{l}\text { State and federal regulation is bringing the country } \\
\text { closer to socialism }{ }^{3}\end{array}$ & 67 & 69 & 56 & 0.14 \\
\hline $\begin{array}{l}\text { Citizens should be able to use natural resources on } \\
\text { their own land without asking state permission }{ }^{3}\end{array}$ & 90 & 84 & 72 & 0.00 \\
\hline
\end{tabular}

${ }^{1}$ Neutral responses excluded from analysis.

${ }^{2} n$ varies slightly with each question.

${ }^{3}$ Used to develop scale of "receptivity to regulation."

${ }^{4}$ ns indicates not significant. 
Table 6. The percentage of California hardwood rangeland landowners with the following reasons to value oaks, and who carried out the following oak management practices in the 5 yr previous to the survey date in 1985, 1992, and 2004.

\begin{tabular}{|c|c|c|c|c|}
\hline & \multicolumn{3}{|c|}{ Landowners (\%) } & \multirow[b]{2}{*}{$P\left(\chi^{2}\right), \mathrm{df}=1,1985$ vs. 2004} \\
\hline & $1985(n=126)^{1}$ & $1992(n=115)^{1}$ & $2004(n=98)^{1}$ & \\
\hline \multicolumn{5}{|l|}{ The respondent values oaks for: } \\
\hline Erosion control & 73 & 83 & 80 & 0.13 \\
\hline Wildlife habitat & 80 & 84 & 86 & $n s^{2}$ \\
\hline Natural beauty & 84 & 87 & 86 & ns \\
\hline Property value & 57 & 61 & 60 & ns \\
\hline Shade & 77 & 79 & 70 & 0.17 \\
\hline Browse & 51 & 67 & 68 & 0.01 \\
\hline Having more forage underneath & 29 & 37 & 35 & ns \\
\hline Conserving water & 46 & 58 & 62 & 0.05 \\
\hline Fuelwood & 63 & 57 & 37 & 0.00 \\
\hline \multicolumn{5}{|c|}{ Management practices carried out in the $5 \mathrm{yr}$ previous to the survey date: } \\
\hline Improve wildlife habitat & 37 & 44 & 47 & 0.14 \\
\hline Plant oaks & 6 & 14 & 32 & 0.00 \\
\hline Cut mistletoe out of trees & 21 & 19 & 29 & 0.17 \\
\hline Divert water from stream or spring & - & 33 & 25 & $0.18^{3}$ \\
\hline Stabilize stream banks & 17 & 30 & 25 & 0.04 \\
\hline Build stream erosion control structures & - & 14 & 22 & $0.09^{3}$ \\
\hline Stream channelization & - & 20 & 11 & $0.09^{3}$ \\
\hline Fence riparian areas & 17 & 25 & 21 & ns \\
\hline Cut oaks and treat stumps & 16 & 13 & 16 & ns \\
\hline Burn scrub oaks & 12 & 11 & 8 & ns \\
\hline Thin softwoods to promote oaks & 12 & 9 & 9 & ns \\
\hline Spray, poison, girdle oaks & 7 & 2 & 1 & 0.04 \\
\hline Thin oaks & 35 & 26 & 34 & ns \\
\hline Cut or remove any oaks & 85 & 76 & 65 & 0.00 \\
\hline Cut living oaks & 43 & 29 & 32 & 0.02 \\
\hline \multicolumn{5}{|l|}{ Cuts oaks and agrees an important reason is: } \\
\hline Removing dead or diseased oaks & 74 & 72 & 60 & 0.07 \\
\hline Improving access & 36 & 25 & 25 & 0.06 \\
\hline Home firewood & 41 & 24 & 16 & 0.00 \\
\hline Increasing forage production & 39 & 23 & 24 & 0.03 \\
\hline Increasing water flow & 20 & 12 & 14 & ns \\
\hline Clearing for development & 17 & 11 & 9 & 0.07 \\
\hline
\end{tabular}

${ }^{1} n$ varies slightly with each question.

${ }^{2}$ ns indicates not significant; na, not applicable.

${ }^{3}$ Compares 1992 and 2004.

$10 \mathrm{yr}$. Those planning to dispose of their property in the next $10 \mathrm{yr}$ were more interested in donating or selling easements than those planning to keep their properties over the next decade $(67 \%$ vs. $35 \% ; P<0.07, \mathrm{df}=1)$.

\section{DISCUSSION}

Overall, relationships between property size and the goals, attitudes, and practices of landowners remain consistent with the simple typology developed from the 1985 survey, where properties $<80$ ha, 80 ha to 2008 ha, and $>2008$ ha were compared (Huntsinger and Fortmann 1990). Summarizing the results for then and now, owners of larger properties usually produce livestock and live in the woodlands primarily because of a family business, participate in voluntary land conservation programs such as the CLCA, more often live on their oak woodland properties year-round, have stronger antiregulation sentiments, cut some oaks from their land, are concerned about oaks suppressing forage production, and get their information from advisory agencies, professional associations, and Cooperative Extension. The growing numbers of smaller parcel holders do not usually sell products, graze livestock, or cut oaks, and are more amenable to regulations for conserving oaks. More often they are absentee owners, have owned their land for less time, and are unlikely to have received or used information about oaks from any major advisory organization. Owners of smaller properties primarily live in the woodlands to enjoy its natural beauty and to "get away from the city." Unless differences associated with property size have changed since the 
Table 7. The percent of hardwood rangeland landowners that agree or disagree with the following statements who have cut or planted oaks in the five years previous to 2004. To be read, for example, as "Of landowners who agree that oak replacement is adequate on their land, $82 \%$ cut some oaks in the previous five years, while of those who disagree, $48 \%$ cut some oaks during this period."

\begin{tabular}{|c|c|c|c|}
\hline Statement & $\begin{array}{c}\% \text { that } \\
\text { agree \& } \\
\text { cut oaks }\end{array}$ & $\begin{array}{c}\% \text { that } \\
\text { disagree \& } \\
\text { cut oaks }\end{array}$ & $\begin{array}{c}P\left(\chi^{2}\right) \\
n=96^{1}\end{array}$ \\
\hline Oak replacement is adequate on my land & 82 & 48 & 0.01 \\
\hline Oak canopy is greater than $50 \%$ on my land & 94 & 57 & 0.01 \\
\hline Oak harvest should be regulated & 39 & 75 & 0.00 \\
\hline Oaks are being lost in California & 53 & 79 & 0.01 \\
\hline \multicolumn{4}{|l|}{ I have/am interested in a conservation } \\
\hline \multirow[t]{2}{*}{ easement } & 57 & 76 & 0.07 \\
\hline & $\begin{array}{l}\% \text { that } \\
\text { agree \& } \\
\text { plant oaks }\end{array}$ & $\begin{array}{c}\% \text { that } \\
\text { disagree \& } \\
\text { plant oaks }\end{array}$ & $\begin{array}{l}P\left(\chi^{2}\right) \\
n=96^{1}\end{array}$ \\
\hline \multicolumn{4}{|l|}{ Oak replacement is inadequate on my } \\
\hline property & 46 & 32 & 0.06 \\
\hline I live on my property all year & 37 & 18 & 0.11 \\
\hline Oaks are valuable for habitat & 37 & 7 & 0.03 \\
\hline Oaks are valuable for natural beauty & 37 & 7 & 0.03 \\
\hline Oaks are valuable for browse & 41 & 13 & 0.00 \\
\hline Oaks are valuable for firewood & 22 & 38 & 0.10 \\
\hline \multicolumn{4}{|l|}{ I have/am interested in a conservation } \\
\hline easement & 45 & 23 & 0.06 \\
\hline I used UC advisory services (previous 2 yr) & 57 & 27 & 0.03 \\
\hline I used any advisory service (previous 2 yr) & 50 & 26 & 0.03 \\
\hline
\end{tabular}

${ }^{1} n$ varies slightly with each question, $\mathrm{df}=1$.

earlier surveys, they were not reported here because they are described in Huntsinger and Fortmann (1990). However, when considering all landowners, there are changes in land use, income source, management, and attitudes about oak woodlands, when comparing 1985 and 2004 results.

Since 1985, changes that reflect IHRMP goals have occurred in the practices and values of hardwood rangeland landowners. Although the survey cannot "prove" these changes are a result of the program, there has been a shift to stewarding and valuing oaks. Outreach and education programs oriented toward nonproduction landowners, land trusts, and other "conservation owners" are needed, as well as research on the functioning of "working landscapes" programs-programs that seek to use privately owned production enterprises for land and habitat conservation, and to provide ecosystem services (Kreuter et al. 2006).

\section{Hardwood Rangelands as "Working Landscapes"}

The major hardwood rangeland land use remains livestock grazing and production, but more landowners, including ranchers, now report they value diverse ecological, cultural, and lifestyle benefits from oak woodland properties. These benefits or amenities fall well within the definition of ecosystem services, "the condition and processes through which natural ecosystems, and the species that make them up, sustain and fulfill human life" (Daily 1997). Many of the ecosystem
Table 8. Percentage of hardwood rangeland landowners with the following attitudes towards conservation easements in 2004.

\begin{tabular}{lc}
\hline & $\begin{array}{c}\text { Respondents, } \\
2004(\%)\end{array}$ \\
\hline Among all respondents ( $n=99)$ & 64 \\
Have a conservation easement & 10 \\
Do not have a conservation easement & \\
Do not know what a conservation easement is & \\
Among respondents knowing about conservation easements & 26 \\
$\quad$ but without one ( $n=82)$ & 49 \\
Have been approached about a conservation easement & 26 \\
Would not consider selling or donating an easement & 11 \\
I would consider selling & 20 \\
I would consider donating & \\
I do not know enough about it & \\
Of those who know enough about easements to answer & 13 \\
$\quad$ ( $n=76)$ & 22 \\
I would donate to a public agency & 11 \\
I would donate to a land trust or other private NGO & \\
It makes no difference to me &
\end{tabular}

services valued by landowners, such as natural beauty and wildlife habitat, are shared by society and benefit the public. Some ecosystem services are consumed mostly by the landowner, as with an enjoyment of the lifestyle of owning and managing oak woodland, and the satisfaction of having property to leave to heirs. Although in surveys ranchers consistently rate the monetary profits of ranching low as an overall motive for ranching, this survey and many other studies of Western rangeland owners have reported strong ecosystem service motivations for landownership and management decisions (Smith and Martin 1972; Bartlett et al. 1989; Huntsinger and Fortmann 1990; Liffmann et al. 2000; Rowe et al. 2001; Torell et al. 2001; Gentner and Tanaka 2002; Gosnell and Travis 2005; Campos et al. 2009). Oak woodland ranchers are therefore engaged in the joint production of ecosystem services and production of food and fiber, which is the conceptual underpinning of "working landscapes" as a conservation goal (Huntsinger and Sayre 2007).

Part of the working landscapes idea is that management activities of ranchers and grazing itself may be considered ecosystem services when they augment or support environmental benefits. In some woodland areas oak recruitment might be augmented by removal of livestock grazing (Tyler et al. 2006) when other factors, such as drought and insect and mammalian herbivores, are not suppressing seedling growth. On the other hand, there are some settings where livestock grazing has a role in maintaining wildlife habitat and ecosystem services at multiple scales: at the landscape scale, extensive ranching properties provide contiguous habitat that offers the best opportunity for the survival of many species; at ranch and pasture scales, activities such as stock pond maintenance can benefit wildlife (US Department of the Interior-Fish and Wildlife Service 2006); and grazing at the plant community scale can support species of concern (Weiss 1999; Marty 2005, Pyke and Marty 2005; DiDonato 2007). Grazing is broadly considered to be useful in diminishing fire hazard in California, by reducing 
fine fuels and suppressing brush. Management can enhance the use of grazing to meet conservation goals, and reduce potential problems including overgrazing, soil and stream bank erosion, introduction of invasive species, grazing of species of concern, and water contamination. Using working landscapes to meet conservation goals involves developing management strategies and technologies that reduce conflict between production and conservation activities and enhance synergies (Brunson and Huntsinger 2008).

\section{Emerging Markets for Ecosystem Services}

When many people think about markets for ecosystem services, they think of the Chicago Climate Exchange or other organizations that offer payments for carbon sequestration on rangelands. However, less obviously, various policies and private demand have created relatively longstanding "markets" for ecosystem services that have placed a monetary value on services such as lifestyle benefits, undeveloped land, targeted grazing, wildlife habitat improvement, grass-fed meats, and water quality protection. Cost-sharing programs for water quality or wildlife improvements, payment for conservation easements, valueadded prices for grass-fed meat, and tax relief for land conservation all place a monetary value on the production of ecosystem services desired by society. Amenity-driven land prices for rangeland, and the willingness of ranchers to subsidize ranches and forgo opportunity costs, are part of the price that ranchers and landowners pay for the ecosystem services they consume and can be used to determine at least a minimum monetary value for services that are considered difficult to value, such as a beautiful view or the ranching lifestyle (Torell et al. 2005; Campos et al. 2009). There are also markets specifically for grazing. In California, payment for prescription grazing is a growing market, and in the case of goats used for brush reduction, can bring in more than $\$ 700.00 \cdot \mathrm{ha}^{-1}$.

Numerous surveys have documented and reflected on the tendency of ranchers to supplement ranch income with outside work by members of the household (Smith and Martin 1972; Workman and Evans 1993; Liffmann et al. 2000). This study showed that hardwood rangeland landowners were more likely to be obtaining a majority of their income from off-ranch sources in 2004 than they were on previous sample dates. Owner subsidies for ranch operations translate into what ranchers "pay" to ranch and to consume the associated ecosystem services (Martin and Jeffries 1966; Marsh and Sumner 1999; Torell and Bailey 2000; Torell et al. 2001, 2005). Surveys show that ranchers are well aware of how much they are paying for the lifestyle and the other ecosystem services they value and consume (Rowe et al. 2001; Sulak and Huntsinger 2002). In addition, oak woodland land prices reflect such values, as they are considerably higher than the prices that can be justified by agricultural production alone (Torell and Kincaid 1996). Unfortunately, one of the ways that the owners of large oak woodland properties can "cash out" this value after years of marginally or occasionally profitable livestock production and lost opportunity cost is to sell to developers (Hargreave 1993). This does not foster oak woodland sustainability, and results in the loss of ecosystem services valued by society.

A trend toward stronger amenity-related motives for ranchers and owners of larger properties has positive as well as potentially negative aspects, and creates some unknowns (Fig. 2). That landowners recognize and appreciate ecosystem services would suggest that they are better equipped to manage for them, aiding themselves and society, and to take advantage of emerging and potential markets for carbon sequestration, habitat restoration and protection, and so forth. On the other hand, recent research indicates that amenity values or landowner-consumed ecosystem service values reach a saturation point, and that keeping a large property intact is not necessary to satisfy the landowner's desire for amenities: most of these values, as with natural beauty, or a different lifestyle, can be satisfied with a property of a few hectares (Campos et al. 2009). The results of this study are illustrative, as owners of even small properties perceive high amenity values for their properties. On the other hand, those producing livestock or other products where income increases as the number of hectares owned increases are highly motivated to keep land intact (Campos et al. 2009). Markets for maintaining undeveloped land and wildlife habitat, value-added livestock products, and other goods and services that provide income streams that increase with the size of holdings can also help to reduce subdivision and land fragmentation.

\section{IMPLICATIONS}

Programs that will help livestock producers to jointly produce ecosystem services and livestock products are needed to conserve unfragmented private rangelands. This includes developing management strategies that create production and conservation synergies, and developing income streams for ecosystem service provisioning that increase as the area conserved increases. Hardwood rangeland landowners and rangeland landowners in much of the West have demonstrated a willingness to financially support the production of ecosystem services from rangelands that benefit society. However, the high costs reduce profitability and enterprise sustainability. Through policy mechanisms and markets, society can share some of the costs of production of ecosystem service production and stimulate increased services of public benefit. Half of the landowners in the survey indicated that they were receptive to environmental regulation, if it came with "compensation" that shared the cost of compliance. On the other hand, some public policy initiatives, regulations, and social trends may detract from the benefits reaped by the landowner, and eventually weaken landowner willingness or ability to continue ranching or landownership. We tend to think of landowner costs in terms of money, but "costs" can be a reduction in any of the ecosystem services consumed by the landowner or rancher, including a reduction in the enjoyment of lifestyle and work, or a belief that society is hostile to ranching (Liffmann et al. 2000).

Finally, most cost-sharing programs and many other conservation incentives programs do not necessarily address land use stability - a landowner might obtain public funds for pond restoration one year and sell the land for development the next, making such public investments risky. However, results here appear to indicate that landowners who want their land to remain intact, as indicated by having or being interested in conservation easements, are more likely to engage in restoration practices such as planting oaks. In contrast to a posited "impermanence syndrome" that states that an uncertain future for the land leads to property neglect or "a lack of confidence in 
the stability and long-run profitability of farming in urbanized areas, leading to disinvestment of human and capital resources" (Heimlich and Anderson 1987; Heimlich 1989), we could posit here a "permanence syndrome," where landowners envisioning a long time horizon for their land as a ranch or woodland are more active conservationists. Therefore, the interlinkage of land use stability and management incentives could prove mutually reinforcing, with feedbacks resulting in higher levels of efficiency in conservation.

\section{ACKNOWLEDGMENTS}

Thanks are especially due to the landowners of California's oak woodlands, especially those who have stalwartly participated in this survey over the years. Adriana Sulak, Jose Oviedo-Pro, and Adina Rissmann all contributed their expertise to aspects of the research and write-up. Thanks to the journal reviewers and Paul F. Starrs for their very helpful reviews.

\section{LITERATURE CITED}

Allen-Diaz, B., J. Bartolome, and M. P. McClaran. 1999. California oak savanna. In: R. C. Anderson, J. S. Fralish, and J. M. Baskin [EDs.]. Savannas, barrens, and rock outcrop plant communities of North America. Cambridge, United Kingdom: Cambridge University Press. p. 332-329.

Allen-Diaz, B., R. Standiford, and R. D. Jackson. 2007. Chapter 12: oak woodlands and forests. In: M. G. Barbour, T. Keeler-Wolf, and A. A. Schoenherr [EDS.]. Terrestrial vegetation of California. Berkeley, CA, USA: University of California Press. p. 315-330.

Bartlett, E. T., R. G. Taylor, J. R. McKean, and J. G. Hof. 1989. Motivation of Colorado ranchers with federal grazing allotments. Journal of Range Management 42(6):454-457.

BolsINGER, C. 1988. The hardwoods of California's timberlands, woodlands, and savannas. Portland, OR, USA: US Forest Service, Pacific Northwest Forest and Range Experiment Station Research Bulletin PNW-RB-148. 148 p.

Brodt, S., K. Klonsky, L. Tourte, R. Duncan, L. Hendricks, C. Ohmart, and P. Verdegaal. 2004. Influence of farm management style on adoption of biologically integrated farming practices in California. Renewable Agriculture and Food Systems 19(4):237-247.

Brunson, M. W., AND L. Huntsinger. 2008. Ranching as a conservation strategy: can old ranchers save the new west? Rangeland Ecology \& Management 61(2):137-147.

Burcham, L. T. 1982. California range land: an historico-ecological study of the range resource of California. Davis, CA, USA: University of California. $261 \mathrm{p}$.

Campos, P., J. L. Oviedo, A. Caparrós, L. Huntsinger, and I. Coelho. 2009. Contingent valuation of woodland-owners private amenities in Spain, Portugal, and California. Rangeland Ecology \& Management 2(3):240-252.

[CDF-Frap] Callfornia Department of Forestry and Fire Protection-Fire and Resource Assessment Program. 2003. Changing California: forest and range 2003 assessment. Sacramento, CA, USA: California Department of Forestry and Fire Protection. $126 \mathrm{p}$.

Clendenning, G., D. R. Field, and D. Jensen. 2004. A survey of seasonal and permanent landowners in Wisconsin's northwoods: following Dillman and then some. Society \& Natural Resources 17(5):431-442.

Conley, J. L., M. E. Fernandez-Gimenez, G. B. Ruyle, and M. Brunson. 2007. Forest Service grazing permittee perceptions of the endangered species act in southeastern Arizona. Rangeland Ecology \& Management 60(2):136-145.

Coppock, D. L., And A. H. BiRkenfeld. 1999. Use of livestock and range management practices in Utah. Journal of Range Management 52(1):7-18.

DalLy, G. C. 1997. Nature's services: societal dependence on natural ecosystems. Washington, DC, USA: Island Press. $392 \mathrm{p}$.

DiDonato, J. 2007. Endangered amphibian research within grazed grasslands. Keeping Landscapes Working, University of California Cooperative Extension
Newsletter for Rangeland Managers Winter:4-6. Available at: http:// cesantaclara.ucdavis.edu/newsletterfiles/newsletter710.htm. Accessed 25 March 2010.

Dilıman, D. A. 1978. Mail and telephone surveys: the total design method. New York, NY, USA: John Wiley and Sons. $344 \mathrm{p}$.

Ewing, R. A., N. Tosta, R. Tuazon, L. Huntsinger, R. Marose, K. Nielson, R. Motroni, AND S. TURAN. 1988. California's forests and rangelands: growing conflict over changing resources: an assessment. Sacramento, CA, USA: California Department of Forestry and Fire Protection. $242 \mathrm{p}$.

Fortmann, L., And L. Huntsinger. 1989. The effects of nonmetropolitan population growth on resource management. Society \& Natural Resources 2(1):9-22.

Gentner, B. J., and J. A. Tanaka. 2002. Classifying federal public land grazing permittees. Journal of Range Management 55(1):2-11.

Gosnell, H., J. H. Haggerty, and P. A. Byorth. 2007. Ranch ownership change and new approaches to water resource management in southwestern Montana: implications for fisheries. Journal of the American Water Resources Association 43(4):990-1003.

Gosnell, H., and W. R. Travis. 2005. Ranchland ownership dynamics in the Rocky Mountain west. Rangeland Ecology \& Management 58(2):191-198.

Hargreave, T. 1993. The impact of a federal grazing fee increase on land use in El Dorado County, California [thesis]. Berkeley, CA, USA: University of California. 68 p.

Heimlich, R. E. 1989. Metropolitan agriculture; farming in the city's shadow. Journal of the American Planning Association 55:457-466.

Heimlich, R. E., and W. D. Anderson. 1987. Dynamics of land use change in urbanizing areas: experience in the economic research service. In: WilliamLockeretz [ED.]. Sustaining agriculture near cities. Washington, DC, USA: Soil and Water Conservation Service. p. 135-154.

Holzman, B. A. 1993. Vegetation change in California's blue oak (Quercus douglasii) woodlands [dissertation]. Berkeley, CA, USA: University of California. $120 \mathrm{p}$.

Huntsinger, L., L. Buttolph, and P. Hopkinson. 1997. Ownership and management changes on California hardwood rangelands: 1985 to 1992. Journal of Range Management 50(4):423-430.

Huntsinger, L., and L. P. Fortmann. 1990. California's privately owned oak woodlands: owners, use, and management. Journal of Range Management 43(2):147-152.

Huntsinger, L., AND P. Hopkinson. 1996. Viewpoint: sustaining rangeland landscapes: a social and ecological process. Journal of Range Management 49(2):167-173.

Huntsinger, L., M. Johnson, M. Stafford, and J. Fried. 2008. A resurvey of oak woodland landowners: 1985, 1992, and 2004. In: A. Merenlender, D. McCreary, and K. L. Purcell [TECH. EDS.]. Proceedings, 6th Symposium on Oak Woodlands: California's Oaks, Today's Challenges, Tomorrow's Opportunities; 9-12 October 2007; Santa Rosa, CA, USA. Albany, CA, USA: USDA Forest Service Pacific Southwest Research Station General Technical Report PSW-GTR-217. p. 57-68. Available at: http://www.fs.fed.us/psw/publications/ gtrs.shtml. Accessed 10 December 2009.

Huntsinger, L., and N. Sayre. 2007. Introduction: the working landscapes special issue. Rangelands 23(3):9-13.

Huntsinger, L., A. Sulak, L. GWin, And T. Plieninger. 2004. Oak woodland ranchers in California and Spain: conservation and diversification. Advances in Geoecology 31:309-326.

Jackson-Smith, D., U. Kreuter, and R. S. Krannich. 2005. Understanding the multidimensionality of property rights orientations: evidence from Utah and Texas ranchers. Society \& Natural Resources 18(7):587-610.

JoHnson, S. G. 1997. Factors contributing to land-use change in the hardwood rangelands of two central Sierra Nevadan counties. In: N. H. Pillsbury, J. Verner, and W. D. Tietje [TECH. COORDS.]. Proceedings of a Symposium on Oak Woodlands: Ecology, Management, and Urban Interface Issues; 19-22 March 1997; San Luis Obispo, CA, USA. Albany, CA, USA: USDA Forest Service Pacific Southwest Research Station General Technical Report PSW-GTR-160. p. $592-602$.

Kreuter, U. P., M. V. Nair, D. Jackson-Smith, J. R. Conner, and J. E. Johnston. 2006. Property rights orientations and rangeland management objectives: Texas, Utah, and Colorado. Rangeland Ecology \& Management 59(6):632-639. 
Kreuter, U. P., M. R. Tays, and J. R. Conner. 2004. Landowner willingness to participate in a Texas brush reduction program. Journal of Range Management 57(3):230-237.

LaBovitz, S. 2006. Criteria for selecting a significance level: a note on the sacredness of .05. In: D. Morrison and R. Henkel [EDS.]. The significance test controversy. New Brunswick, NJ, USA: Aldine Transaction. p. 166-171.

Larson, S., K. Smith, D. Lewis, J. Harper, and M. George. 2005. Evaluation of California's rangeland water quality education program. Rangeland Ecology \& Management 58(5):514-522.

Liffmann, R. H., L. Huntsinger, and L. C. Forero. 2000. To ranch or not to ranch: home on the urban range? Journal of Range Management 53(4):362-370.

MARSH, L., AND D. SUMner. 1999. Effects of policy risk on rancher wealth and range health: grazing permits in the western United States. American Journal of Agricultural Economics 81:1303-1303.

Martin, W. E., AND G. L. JefFRies. 1966. Relating ranch prices and grazing permit values to ranch productivity. Journal of Farm Economics 48:233-342.

MARTY, J. T. 2005. Effects of cattle grazing on diversity in ephemeral wetlands. Conservation Biology 19:1626-1632.

McClaran, M. P., and J. W. Bartolome. 1985. The importance of oaks to ranchers in the California foothill woodland. Rangelands 7:158-161.

Muick, P. C., AND J. W. BARTOLOME. 1987. An assessment of natural regeneration of oaks in California. Sacramento, CA, USA: California Department of Forestry and Fire Protection. $36 \mathrm{p}$.

Myers, N., R. A. Mittermeier, C. G. Mittermeier, G. A. B. Da Fonseca, and J. Kent. 2000. Biodiversity hotspots for conservation priorities. Nature 403:853-858.

Pyke, C. R., AND J. Marty. 2005. Cattle grazing mediates climate change impacts on ephemeral wetlands. Conservation Biology 19:1619-1625.

Richards, R. T., AND M. R. GEORGE. 1996. Evaluating changes in ranch management practices through extension education. Journal of Range Management 49:76-80.

Rowan, R. C., AND L. D. White. 1994. Regional differences among Texas rangeland operators. Journal of Range Management 47:338-343.

Rowe, H. I., E. T. Bartlett, and L. E. Swanson, JR. 2001. Ranching motivations in two Colorado counties. Journal of Range Management 54:314-321.

Smith, A. H., And W. E. Martin. 1972. Socioeconomic behavior of cattle ranchers, with implications for rural community development in the west. American Journal of Agricultural Economics 54:217-225.

SPICER, C. C. 1972. Calculation of power sums of deviations about the mean. Applied Statistics 21:226-227.

SteWART, W. 1991. Monitoring values and practices of oak woodland decisionmakers on the urban fringe. In: R. B. Standiford [TECH. COORD.] Symposium on Oak Woodlands and Hardwood Rangeland Management; 31 October-2 November 1990; Davis, CA, USA. Albany, CA, USA: USDA Forest Service Pacific Southwest Research Station General Technical Report PSW-GTR-126. p. $174-181$

SulaK, A., AND L. HUntsinger. 2002. Sierra Nevada grazing in transition: the role of Forest Service grazing in the foothill ranches of California. A report to the Sierra Nevada Alliance, the California Cattlemen's Association, and the California Rangeland Trust. Available at: http://www.sierranevadaalliance.org/ publications/publication.shtml?type =pgm02. Accessed 1 May 2009.
Sulak, A., L. Huntsinger, S. J. Barry, and L. Forero. 2008. Public land grazing for private land conservation? In: A. Merenlender, D. McCreary, and K. L. Purcell [TECH. EDS.]. Proceedings, 6th Symposium on Oak Woodlands: California's Oaks, Today's Challenges, Tomorrow's Opportunities; 9-12 October 2007; Santa Rosa, CA, USA. Albany, CA, USA: USDA Forest Service Pacific Southwest Research Station General Technical Report PSW-GTR-217. p. 7-18. Available at: http://www.fs.fed.us/psw/publications/gtrs.shtml. Accessed 10 December 2009.

Swiecki, T. J., E. A. Bernhardt, and C. Drake. 1997. Factors affecting blue oak sapling recruitment. In: N. H. Pillsbury, J. Verner, and W. D. Tietje [теCH. CooRDs.]. Proceedings of a Symposium on Oak Woodlands: Ecology, Management, and Urban Interface Issues; 19-22 March 1997; San Luis Obispo, CA, USA. Albany, CA, USA: USDA Forest Service Pacific Southwest Forest and Range Experiment Station General Technical Report. PSW-160. $p$. 157-167.

ToreLL, L. A., AND S. A. Balley. 2000. Is the profit motive an important determinant of grazing land use and rancher motives? Journal of Agricultural and Resource Economics 25:725-725.

ToreLL, L. A., And M. E. Kincaid. 1996. Public land policy and the market value of New Mexico ranches, 1979-94. Journal of Range Management 49:270-276.

Torell, L. A., N. R. Rimbey, O. A. Ramirez, and D. W. McCollum. 2005. Income earning potential versus consumptive amenities in determining ranchland values. Journal of Agricultural and Resource Economics 30:537-560.

Torell, L. A., N. R. Rimbey, J. A. TanakA, and S. A. Balley. 2001. The lack of profit motive for ranching: implications for policy analysis. Available at: http://www. publiclandsranching.org/htmlres/resources.htm\#economics. Accessed 19 December 2009

Tyler, C. M., B. Kuhn, and F. W. Davis. 2006. Demography and recruitment limitations of three oak species in California. Quarterly Review of Biology 81(2):127-152.

US Department of Agriculture, Forest Service. 1981. Resource evaluation field instructions for California, 1981-1984. Portland, OR, USA: Pacific Northwest Forest and Range Experiment Station. $36 \mathrm{p}$.

US Department of the InterioR-Fish and Wildiffe Service. 2006. Designation of critical habitat for the California red-legged frog, and special rule exemption associated with final listing for existing routine ranching activities; final rule. 71 FR 19243 19346. Available at http://ecos.fws.gov/speciesProfile/ SpeciesReport.do?spcode=D02D. Accessed 6 December 2009.

WeISS, S. B. 1999. Cars, cows, and checkerspot butterflies: nitrogen deposition and management of nutrient-poor grasslands for a threatened species. Conservation Biology 13:1476-1486.

Wensel, L. 1983. Estimators for use in California forestland ownership studies. Berkeley, CA, USA: University of California Department of Forestry and Resource Management Biometrics Note 8. 26 p.

Workman, J. P., and S. G. Evans. 1993. Utah ranches-an economic snapshot. Rangelands 15:253-255.

Yung, L., AND J. M. Belsky. 2007. Private property rights and community goods: negotiating landowner cooperation amid changing ownership on the rocky mountain front. Society \& Natural Resources 20:689-703. 